\title{
Optimal Conditions for Naphthalene Biodegradation by Local Bacterial Isolates
}

\author{
Zainab Hani Hatef ${ }^{1}$, Saad Hussain Khudeir ${ }^{2}$ \\ ${ }^{1,2}$ Ministry of Science and Technology, Directorate of Water and Environment, Iraq
}

\begin{abstract}
Polycyclic aromatic hydrocarbons (PAHs) are non-polar organic compounds consist of two or more fused benzene rings, arranged in linear, angular or clustered structures. The present study aims to find the optimal conditions for studied bacterial isolates (PS6, DR10 and Ja.2) to degrade naphthalene in liquid BH medium using the bacterial growth and biodegradation percentage of naphthalene as indicators. The three isolate were identified as Pseudomonas putida, Burkholderia cepacia and Acinetobacter baumannii respectively according to the results obtained from biochemical tests and vitek2 system. The optimum incubation period, temperature, $\mathrm{pH}$ and naphthalene concentration for Pseudomonas putida, Burkholderia cepacia and Acinetobacter baumannii were determined. Results showed that the maximum growth and biodegradation for naphthalene by three isolates happened after 10 days of incubation at $35^{\circ} \mathrm{C}$, in $\mathrm{BH}$ medium adjusted to $\mathrm{pH} 7$ and supplemented with $100 \mathrm{mg} / \mathrm{l}$ of naphthalene.The Pseudomonas putida gave highest biodegradation of naphthalene compared with other two isolates.
\end{abstract}

Keywords: Biodegradation; Naphthalene; Bacteria

\section{Introduction}

In the last years, extensive urbanization and rapid industrialization has resulted in the accumulation of a large number of xenobiotic chemicals into the natural environment. The use of numerous aromatic compounds in explosives, dyestuffs, pharmaceuticals and pesticides and the growth of industrialization have contributed very much in the environmental pollution and have attracted considerable attention continuously. Petroleum exploitation, exploration, transportation, consumption, attendant spills and disposal often lead to release of hydrocarbon pollutants into the environment with serious ecological problems (Okoh, 2006).

Polycyclic aromatic hydrocarbons (PAHs) are lipophilic compounds that show high affinity for organic matter, they formed by two or more fused benzene rings in linear, angular or luster arrangements (Cheung and Kinkle, 2001). The simplest structure consists of 2 rings (naphthalene) and very complex structures can be formed by more than 6 rings and alkyl groups. These compounds and their derivatives are produced from incomplete composting of organic materials or from compost of natural process, such as forest fires and volcanic eruptions. Above all, they may produce as a result of human activities. In the most recent decade, some important resources of PAH pollutants have included of industrial products, transportation, waste burning, evaporation and burning of plastic residues (Mrozik et al.,2003). Petroleum refineries can generate significant quantities of PAH- containing oily sludge during the processing of crude oil and landfarming is often used as an economical method of waste treatment and disposal (Ward et al.,2003).

PAHs are an alarming group of substances for humans and other organisms. Many PAHs and their oxidative metabolites are highly toxic, mutagenic and carcinogenic to microorganisms as well as to higher organisms including humans (Samanta et al., 2002).Naphthalene binds covalently to molecules in liver, lung tissues and kidney, thereby enhancing its toxicity; addition it an inhibitor of mitochondrial respiration (Falahatpisheh et al.,2001). Exposure of humans to naphthalene may damage or destroy some of red blood cells. This could cause to have too few red blood cells until human body replaces the destroyed cells. This problem is called hemolytic anemia (Lohmann et al., 2007).

Polycyclic aromatic hydrocarbons are highly resistant molecules that do not easily break down and can persist in the environment and adsorb onto non aqueous soil particles (Haritash and Kaushik, 2009) due to their hydrophobicity , neutrality and low water solubility which decrease their availability (Mohamed et al., 2012 ; Straube et al., 2003). Because of the great number of petroleum contaminated sited requiring cleanup, many mechanical and chemical methods to reduce hydrocarbon pollution are often expensive, time consuming and not environment friendly (Atlas,1995). Therefore, recent studies have focused on bioremediation is a cost-effective approach for decontamination of PAH-contaminated sites and has been extensively used (Xia et al., 2006). Bacteria convert the pollutant organic compounds into less harmful compounds by aerobic and anaerobic respiratory reactions, fermentation, co-metabolism, and de-halogenation; using them as the only source of carbon and energy (Kafilzadeh et al.,2011).

The activity of degrading microorganisms is dependent upon many factors, including: nutrients, oxygen, $\mathrm{pH}$ value, composition concentration and bioavailability of contaminants, chemical and physical characteristic of sites and the pollution history of contaminated environment (Norris 1994; Allard and Neilson 1997; Alexander 1999). A large number of microorganisms able to use PAHs of two and three rings as the sole source of carbon and energy have been reported (Bamforth and Singleton, 2005).

There is a large diversity of bacteria that are able to oxidize PAHs including: Acinetobacter, Aeromonas, Agmenellum, Alcaligenes, Bacillus, Berjerinckia, Burkholderia, Corynebacterium, Flavobacterium, Micrococcus, Moraxella, Mycobacterium, Nocardioides, Pseudomonas, 


\section{International Journal of Science and Research (IJSR) \\ ISSN (Online): 2319-7064}

Index Copernicus Value (2016): 79.57 | Impact Factor (2015): 6.391

Rhodococcus, Streptomyces, Sphingomonas, Stenotrophomonas, Vibrio, Paenibacillus (Kim et al., 2005; Juhasz and Naidu 2000; Daane et al., 2002; Samanta et al., 2002).

\section{Materials and methods}

\section{Bacterial isolates}

The isolates PS6, Ja2 and DR10 were isolated from soil samples contaminated with hydrocarbons which collected from different sites in Baghdad city using Bushnell-Haas medium(BHM) with the following compositions (g/l) ); $\mathrm{NH}_{4} \mathrm{NO}_{3} 1.0, \mathrm{FeCl}_{3} 0.05, \mathrm{KH}_{2} \mathrm{PO}_{4} 1.0, \mathrm{~K}_{2} \mathrm{HPO}_{4} 1.0, \mathrm{MgSO}_{4}$. $0.2, \mathrm{CaCl}_{2}$ 0.02, the $\mathrm{pH}$ was adjusted to 7.0 , then $1 \%$ of crude oil was added as carbon source, the ability of these isolates were tested for naphthalene biodegradation (Kumar et al., 2006). Then the three isolates were identified according to colonies morphology, biochemical tests and the VITEK 2 system was used to confirm their identification.

\section{Determination of naphthalene concentration}

The remaining concentration of naphthalene in liquid $\mathrm{BH}$ medium was recorded at a wavelength of $277 \mathrm{~nm}$ using UV spectrophotometer, after each experiment, the isolates were separated by centrifuge $10 \mathrm{ml}$ of medium at $10,000 \mathrm{rpm}$ for 20 minutes and allowed to settle for 30 minutes to get a clear supernatant. Then $5 \mathrm{ml}$ of the clear supernatant was extracted with $5 \mathrm{ml}$ of hexane for 10 minutes in a separating funnel. The solvent layer in a separating funnel was collected and poured into the cuvettes of the spectrophotometer and the absorbance was recorded and the concentration of naphthalene was determined according to standard curve of pure naphthalene (Rahbari et al., 2011).

\section{Determination of bacterial growth}

The growth of studied isolates in flasks of liquid $\mathrm{BH}$ medium after each experiment was measured at $600 \mathrm{~nm}$ using spectrophotometer (Kumar et al.,2006).

\section{Optimal conditions for naphthalene biodegradation}

Effect of incubation period

To determine the best incubation period for each isolate, $25 \mathrm{ml}$ of liquid $\mathrm{BH}$ medium, $\mathrm{pH} 7$ was put into flasks and sterilized at $121^{\circ} \mathrm{C}$ for $15 \mathrm{~min}$. After sterilization, the flasks were supplemented with $50 \mathrm{ppm}$ of naphthalene, then the flasks were inoculated with bacterial isolates (one isolate for each flask) and incubated in shaker incubator $150 \mathrm{rpm}, 30^{\circ} \mathrm{C}$ at different periods (2, 4, 6, 8, 10, 12 and 14 days), the flasks without inoculum were prepared as positive control for each isolate, also triplicate flasks for each experiment was used. The bacterial growth and the biodegradation rate were determined.

\section{Effect of temperature}

Twenty five milliliter of liquid $\mathrm{BH}$ medium, $\mathrm{pH} 7$ was put into flasks and sterilized at $121^{\circ} \mathrm{C}$ for $15 \mathrm{~min}$. After sterilization, the flasks were supplemented with 50ppm of naphthalene, then the flasks were inoculated with bacterial isolates (one isolate for each flask) and incubated in shaker incubator $150 \mathrm{rpm}$ at different temperatures $(25,30,35,40$ and $45{ }^{\circ} \mathrm{C}$ ) for 10 days, the flasks without inoculum were prepared as positive control for each isolate, also triplicate flasks for each experiment was used. The bacterial growth and the biodegradation rate were determined.

\section{Effect of $\mathrm{pH}$ values}

The best $\mathrm{pH}$ for naphthalene biodegradation by each isolate was determined using $25 \mathrm{ml}$ of liquid $\mathrm{BH}$ medium, the flasks of liquid $\mathrm{BH}$ medium were prepared in different $\mathrm{pHs}$ values $\left(5,6,7,8\right.$ and 9 ) and sterilized at $121^{\circ} \mathrm{C}$ for $15 \mathrm{~min}$, then the flasks were supplement with $50 \mathrm{ppm}$ of naphthalene inoculated with bacterial isolates (one isolate for each flask) and incubated in shaker incubator $150 \mathrm{rpm}$ at $35^{\circ} \mathrm{C}$ for 10 days, the flasks without inoculum were prepared as positive control for each isolate, also triplicate flasks for each experiment was used. The bacterial growth and the biodegradation rate were determined.

\section{Effect of naphthalene concentration}

The effect of naphthalene concentration on biodegradation was studied for each isolate using $25 \mathrm{ml}$ of liquid $\mathrm{BH}$ medium, pH 7 was put into flasks and sterilized at $121^{\circ} \mathrm{C}$ for $15 \mathrm{~min}$, then the flasks were supplemented with different concentrations of naphthalene $(100,200,300,400,500,600$ and $700 \mathrm{ppm}$ ), inoculated with bacterial isolates(one isolate for each flask) and incubated in shaker incubator $150 \mathrm{rpm}$ at $35^{\circ} \mathrm{C}$ for 10 days, the flasks without inoculum were prepared as positive control for each isolate, also triplicate flasks for each experiment was used. The bacterial growth and the biodegradation rate were determined.

\section{Results and discussions}

\section{Identification of bacterial isolates}

The results obtained from tests of bacterial identification (morphology of isolates, biochemical tests and VITEK 2 system) showed that the three isolates PS6, DR10 and Ja2 belong to Pseudomonas putida, Burkholderia cepacia and Acinetobacter baumannii respectively.

\section{Optimal conditions for naphthalene biodegradation}

\section{Effect of incubation period}

The results depending on the growth rates and biodegradation of naphthalene in bacterial cultures of Pseudomonas putida, Burkholderia cepacia and Acinetobacter baumannii showed that the best time for naphthalene biodegradation was 10 days for all studied isolates, where the growth rate of isolates were $0.310,0.266$ and 0.235 respectively as in fig.(1-a), also the biodegradation of naphthalene by pseudomonad putida was $73.22 \%$, while by Burkholderia cepacia and Acinetobacter baumannii were $64.81 \%$ and $53.46 \%$ respectively as in fig.(1-b). Also the results showed that the growth rate for three isolates were increased gradually from 2 to 10 days of incubation and then decreased slightly due to accumulate the intermediate compounds and metabolic substances such as fatty acids, ketones, esters, glycolipid and alcohols, these leads to decrease the $\mathrm{pH}$ and oxygen, then appearance the decline phase (Schmitt et al., 1996; Walker et al., 1976c). 
International Journal of Science and Research (IJSR)

ISSN (Online): 2319-7064

Index Copernicus Value (2016): 79.57 | Impact Factor (2015): 6.391
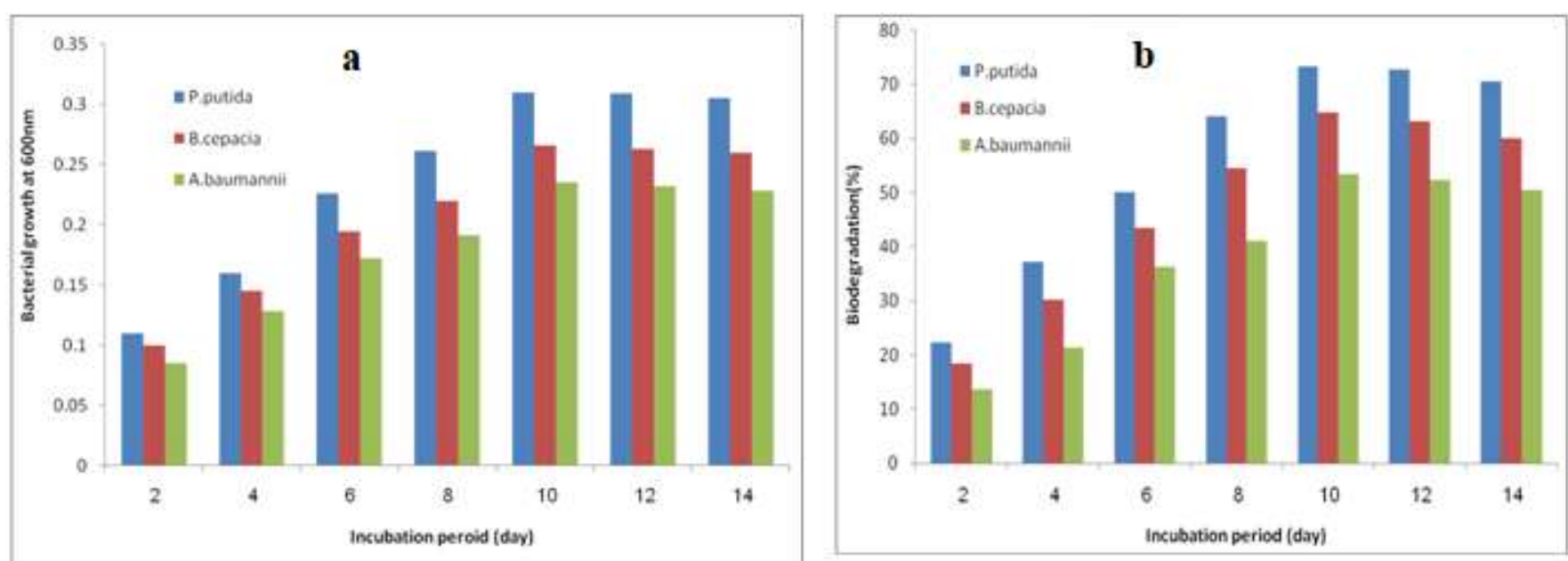

Figure 1: Effect of incubation period on bacterial growth (a) and degradation of naphthalene (b) by three isolates in liquid BH medium

In previous study, Gupta(2012) found the biodegradation efficiency of Pseudomonas sp.S3 was $77.77 \%$ for naphthalene when used 2000 ppm after 7 days of incubation and then decline, while (Kafilzadeh and Pour,2012) found that the naphthalene was completely consumed by pseudomonas sp. and Corynebacterium sp. in medium with $400 \mathrm{ppm}$ after 10 days of incubation.

\section{Effect of temperature}

Temperature has a role in biodegradation of all pollutants because it effects on enzyme activity and microbial growth (Bennett et al., 2012). Results in fig. (2-a) elucidated that the maximum growth rate of three isolates in liquid $\mathrm{BH}$ medium with naphthalene were $0.339,0.288$ and 0.266 for $P$. putida,
B.cepacia and A.baumannii respectively at $35^{\circ} \mathrm{C}$, also the results showed that the P.putida appeared the highest degradation rate for naphthalene $(80.11 \%)$ at $35^{\circ} \mathrm{C}$, compared with other two isolates $B$. cepacia and A.baumannii which were gave $70.89 \%$ and $59.72 \%$ respectively at $35^{\circ} \mathrm{C}$ as in fig.(2-b). Also results demonstrated progressive decrease in bacterial growth for all isolates with increasing temperature above $35^{\circ} \mathrm{C}$, this because the accumulation of metabolites resulting from oxidation processes of bacterial isolates, or to absence of oxygen and nutrients (Bishnoi et al., 2009).
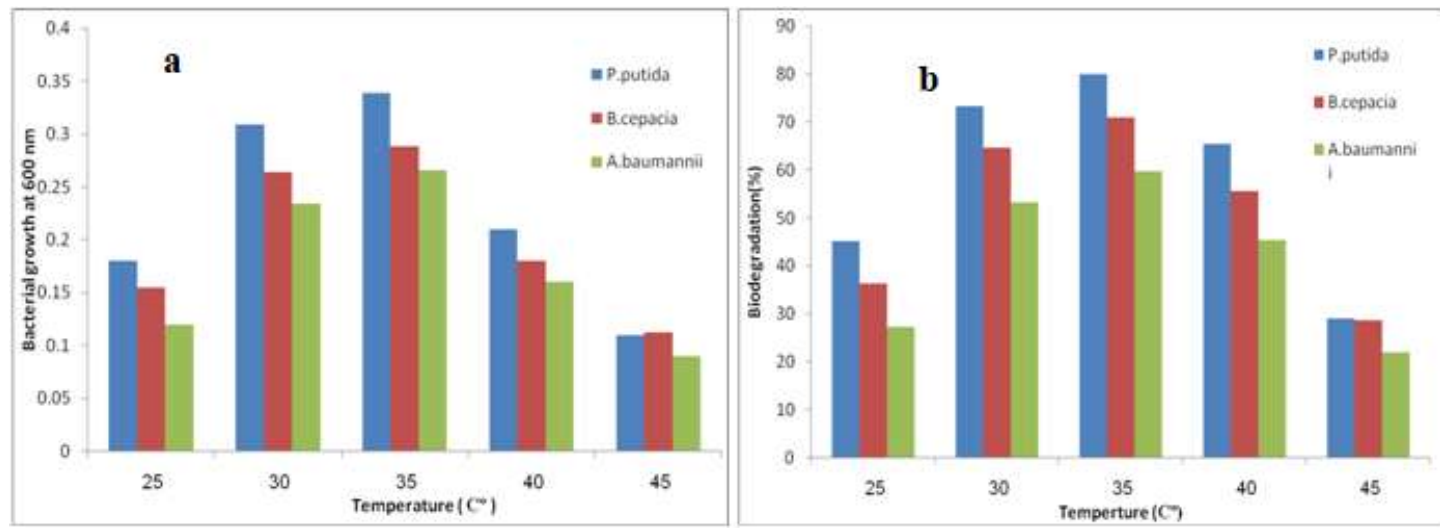

Figure 2: Effect of temperature on bacterial growth (a) and degradation of naphthalene (b) by three isolates in liquid $\mathrm{BH}$ medium

The high temperature decreases the solubility of oxygen and this leads to inhibit the growth of aerobic microbes and then decrease the biodegradation rate (Atlas, 1981; Margesin and Schinner, 2001). Results from Harisha and Lakshmi (2016) showed that the maximum biodegradation of spent engine oil by P.putida was occurred at $35^{\circ} \mathrm{C}$, also Emran (2015) found that the highest rate of growth and degradation for pseudomonas putida occurred at $35^{\circ} \mathrm{C}$, likewise the growth of A.baumannii as optical density with diesel oil was maximum rate at $35^{\circ} \mathrm{C}$ (Palanisamy et al,2014), while Bishnoi et al.,(2009) revealed that the pseudomonas putida and pseudomonas paucimobilis gave maximum biodegradation of pyrene at $30^{\circ} \mathrm{C}$. We concluded from present study and previous studies the optimal temperature for the growth of isolates ranges between $30-35^{\circ} \mathrm{C}$, this may depend on the nature of the isolates and the place where isolated from it.

\section{Effect of pH values}

$\mathrm{pH}$ is one of the major environmental factors that effect on the availability of nutrients, contaminants and activity of biological processes by affects the metabolism of microorganisms and hence the bioremediation kinetics of contaminated soil and water (Ajoku and Oduola, 2013).The obtained results from this experiment as in Fig. (3-a) showed that the highest growth was at $\mathrm{pH} 7$ for all bacterial isolates

\section{Volume 6 Issue 12, December 2017}




\section{International Journal of Science and Research (IJSR) \\ ISSN (Online): 2319-7064 \\ Index Copernicus Value (2016): 79.57 | Impact Factor (2015): 6.391}

after 10 days of incubation with $50 \mathrm{ppm}$ of naphthalene and the P.putida isolate gave the highest growth rate 0.335 , while the growth rate from B. cepacia and A.baummanii were 0.289 and 0.265 respectively. Furthermore the degradation rate of naphthalene by p.putida, B. cepacia and
A.baummanii were $80.21 \%, \quad 70.73 \%$ and $59.74 \%$ respectively at $\mathrm{pH} 7$ as in fig. (3-b).
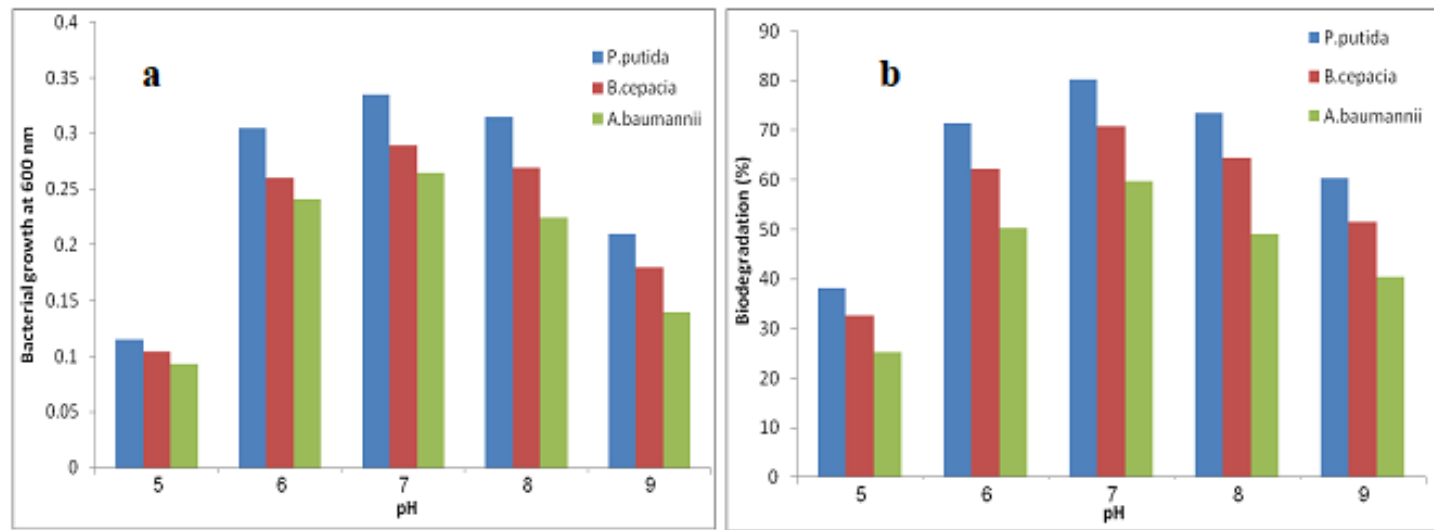

Figure 3: Effect of pHs values on bacterial growth (a) and degradation of naphthalene (b) by three isolates in liquid $\mathrm{BH}$ medium

The pollutants have high mobility at low $\mathrm{pHs}$ values, but the degradation was expected to be limited because the microbial activity was reduced, this may be also due to fact that nutrients are commonly more available at nutral $\mathrm{pH}$ (Chesworth, 2008), while at acidic $\mathrm{pH}$ the anionic nutrients interact with protons and thus less available, Furthermore at basic $\mathrm{pH}$ the cationic nutrients interactions with hydroxyls and thus less available, Whilst at neutral $\mathrm{pH}$ these interactions are reduced and so the nutrients are more available (Chesworth, 2008). Harisha and Lakshmi (2016) proved that the pseudomonas putida gave high growth and biodegradation rate at $\mathrm{pH} 7$, also Sawadogo et al.,(2014) demonstrated that the optimum growth of Acinetobacter at $\mathrm{pH} 7.5$ and 8.5 for Pseudomonas, While Emran (2015) found that $\mathrm{pH} 6$ was suitable for the better growth of Pseudomonas putida grown in medium containing pesticide. Bamforth and Singleton (2005) has reported that $40 \%$ of phenanthrene in a liquid culture at $\mathrm{pH} 5.5$ was degraded by Burkholderia cocovenenas, but the degradation at neutral $\mathrm{pH}$ was $80 \%$. Moreover, Palanisamy et al., (2014) found that the optimal biodegradation for diesel oil by A.baumannii was occurred at pH7 in liquid MSM.

\section{Effect of naphthalene concentration}

The concentration of naphthalene affects the bacterial grow and degradation ability of microorganisms in a contaminated environment, therefore the effect of initial concentration was examined to assess the ability of bacterial isolates to tolerate different concentrations of PAHs (Cerniglia, 1992;Bennett $e t$ al.,2012).
Eight concentrations from naphthalene were used in this experiment; the results showed that $100 \mathrm{mg} / \mathrm{l}$ of naphthalene gave the best growth rate in all isolates after 10 days of incubation than other concentrations, where the growth rate of P.putida, B. cepacia and A.baumannii were 0.366, 0.320 and 0.283 respectively as in fig. (4-a). Also the P.putida was appeared the best ability for naphthalene degradation $86.78 \%$, while B. cepacia and A.baumannii were $75.89 \%$ and $64.95 \%$ respectively as in fig.(4-b). So the results found that the growth rate and degradation rate of all isolates decreased when naphthalene concentrations reached to 600 and $700 \mathrm{mg} / 1$.

The concentration of PAHs has important effect on the potential success of microbial degradation, if the concentrations of PAHs were low, the gene necessary for the production of enzyme may not induced, and the enzymes necessary for degradation may not produce (Van Hamme, 2004), in the other side, if the concentrations of PAHs were high, this may lead to toxic effects upon the cells and toxic metabolites may accumulate in the growth medium (Morasch et al., 2001). In previous study the Pseudomonas sp. degraded $80 \%$ of naphthalene in medium with $400 \mathrm{mg} / \mathrm{l}$ of naphthalene, but the degradation rate was decreased above this concentration (Kafilzadeh et al.,2011), while Kucerova(2006) proved that the pseudomonas putida removal was $81 \%$ of some PAH compounds after 30 days of incubation, also Zhou et al., (2012) found that the two isolate of Pseudomonas sp CZ2 and CZ5 removed 61.8 and $64.3 \%$ of naphthalene with concentration of $1000 \mathrm{ppm}$ after $48 \mathrm{~h}$. 
International Journal of Science and Research (IJSR)

ISSN (Online): 2319-7064

Index Copernicus Value (2016): 79.57 | Impact Factor (2015): 6.391
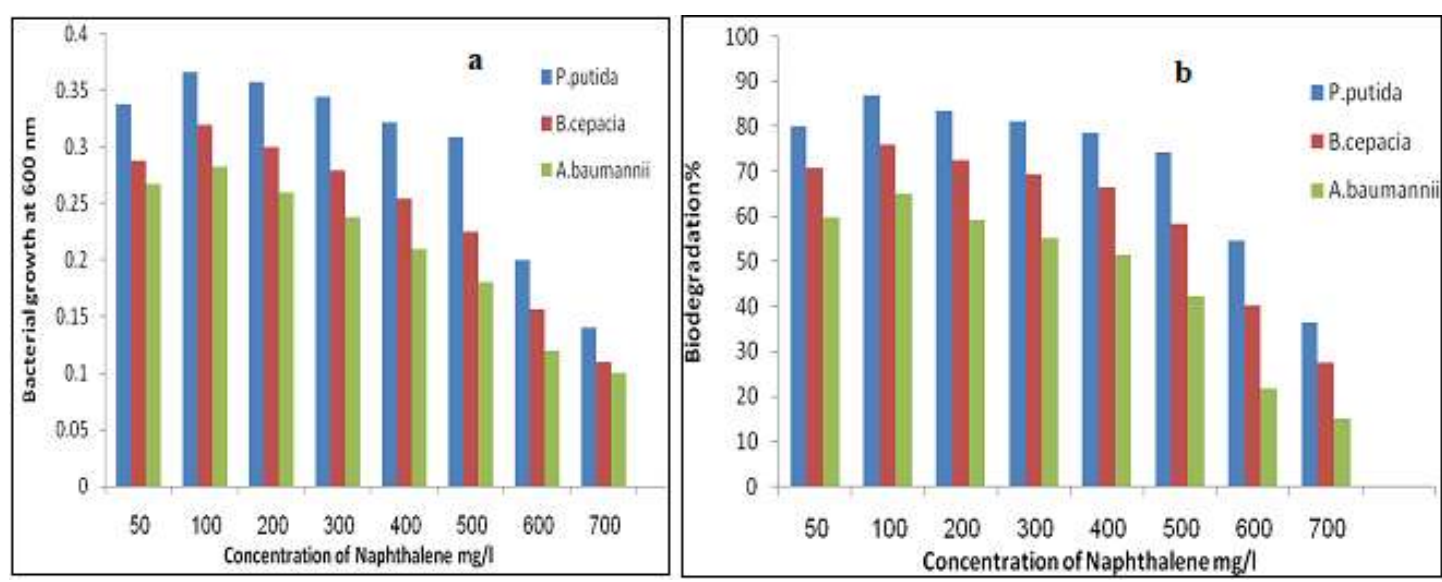

Figure 4: Effect of naphthalene concentrations on bacterial growth (a) and degradation of naphthalene (b) by three isolates in liquid $\mathrm{BH}$ medium

\section{Conclusions}

Contaminated soil with hydrocarbons considered as a good source for the isolation of naphthalene degrading bacteria. The bacterial isolates pseudomonas putida, Burkholderia cepacia and Acinetobacter baumannii have ability to degrade naphthalene under optimum conditions $\mathrm{pH} 7$, concentration of naphthalene $100 \mathrm{ppm}$, temperature $35^{\circ} \mathrm{C}$ and the best time was 10 days. pseudomonas putida showed the highest ability to degrade the naphthalene than other two isolates.

\section{References}

[1] Ajoku, G. A. O. and Oduola, M. K.(2013). Kinetic model of $\mathrm{pH}$ effect on bioremediation of crude petroleum contaminated soil. American Journal of Chemical Engineering, 1(1): 6-10.

[2] Alexander M.(1999). Biodegradation and bioremediation, $2^{\text {nd }}$ end. Academic Press, London.

[3] Allard AS, Neilson AH (1997). Bioremediation of organic waste sites :critical review of microbiological aspects. Int Biodeterior Bioderad 39:253-285.

[4] Atlas, R. M. (1981). Microbial degradation of petroleum hydrocarbons: an environmental perspective: Microbiol. Rev., 45, 180-209.Bakken, L. R. \& Olsen, R. A. (1987). The relationship between cell size and viability of soil bacteria: Microbial Ecology, 13, 103114.

[5] Atlas,R.M.(1995).Bioremediation of petroleum pollutants.Int.Biodeter.Biodegr.,35:317-327.

[6] Bamforth, S. M., and Singleton, I. (2005). Bioremediation of polycyclic aromatic hydrocarbons: current knowledge and future directions. Journal of Chemical Technology and Biotechnology, 80, 723-736.

[7] Bennett, R.M., Dagamac,N.H.A., Fernandez, E.V.A., Uba, M.O. and Ching,M.W.(2012).In Vitro Degradation of Anthracene by Mycobacterium Sp.GIPAH-01 Isolated from Guimaras Island, Philippines.ASIAN J.EXP.BIOL.SCI, 3(4)682-687.

[8] Bishnoi, K.; Sain, U.; Kumar, R.; Singh, R. and Bishnoi, N.R.(2009). Distribution and biodegradation of polycyclic aromatic hydrocarbons in contaminated sites of Hisar (India). Indian J. Exper. Biol., 3:210-217.

[9] Cerniglia,C.E.(1992).Biodegradation of polycyclic aromatic hydrocarbons.Biodegradaio3:351-368.
[10] Chesworth, W. (2008). Encyclopedia of soil science. In Chesworth, W. (Ed.), Soil Chemistry. (pp. 637-640). The Netherlands: Springer.

[11] Cheung PY, Kinkle BK. (2001).Mycobacterium diversity and pyrene mineralization in petroleumcontaminated soils. Appl. Environ. Microbiol;67:22222229.

[12] Daane LL, Harjono I, Barns SM, Launen LA, Palleron NJ, Ha“ggblom MM .(2002) .PAH-degradation by Paenibacillus spp. and description of Paenibacillus naphthalenovorans sp. nov., a naphthalene degrading bacterium from the rhizosphere of salt marsh plants. Int J Syst Evol Microbiol 52:131-139.

[13] Emran,F.K.(2015). Biodegradation of Malathion and Dursban by mono and mixed bacterial cultures. PhD, Thesis, College of science, university of Baghdad.

[14] Falahatpisheh, M.H., K. C. Donnelly and K.S.Ramos.(2001). Antagonistic interactions among nephrotoxic polycyclic aromatic hydrocarbons. J. Toxicol. Environ.Health Perspect, 104:1166-1170.

[15] Gupta,B.(2012).ISOLATION CHARACTERIZATION OF NAPHTHALENE DEGRADING BACTERIA. MSc Thesis, College of Environmental Sciences and Technology . University of Thapar.

[16] Haritash, A. K. and Kaushik, C. P. (2009). Biodegradation aspects of Polycyclic Aromatic Hydrocarbons (PAHs): A review: Journal of Hazardous Materials, 169, 1-15.

[17] Harisha,G.K. $\quad$ and Lakshmi,C.M.V.V.(2016).BIODEGRADATION OF USED ENGINE OIL USING PSEUDOMONAS PUTIDA AND AZOTOBACTER CHROCOOCUM AS BIOSURFACTANT.INTERNATIONAL JOURNAL OF ENGINEERING SCIENCES\&RESEARCH TECHNOLOGY,5(10):245-251.

[18] Juhasz AL, Naidu R. (2000). Bioremediation of high molecular weight polycyclic aromatic hydrocarbons: a review of the microbial degradation of benzopyrene. Int Biodeterior Biodegrad 45:57-88.

[19] Kafilzadeh, F., Rafiee, S. and Tahery, Y. (2011). Evaluation of Bioremediation of naphthalene using native bacteria isolated from oil contaminated soils in Iran. Annals of Biological Research, 2 (6):610-616.

[20] Kafilzadeh, F. and Pour,F. H. (2012).Degradation of naphthalene, phenanthrene and pyrene by pseudomonas

\section{Volume 6 Issue 12, December 2017}




\section{International Journal of Science and Research (IJSR) \\ ISSN (Online): 2319-7064 \\ Index Copernicus Value (2016): 79.57 | Impact Factor (2015): 6.391}

sp. and Corynebacterium sp. in the landfills. International Journal of Biosciences(IJB).2(9):77-84

[21] Kim JD, Shim SH, Lee CG (2005) Degradation of phenanthrene by bacterial strains isolated from soil in oil refinery fields in Korea. J Microbiol Biotechnol 15(2):337-345.

[22] KUCEROVA,R.(2006). APPLICATION OF PSEUDOMONAS PUTIDA AND RHODOCOCCUS SP. BY BIODEGRADATION OF PAH(S), PCB(S) AND NEL SOIL SAMPLES FROM THE HAZADOUS WAST DUMP IN POZDATKY(CZECH REPUBLIC). Rudarsko-geolosko-naftinzbornik,18:97-101.

[23] Kumar,M., Leona,V., Materanoa,A.D.S., Ilzinsa,O.A., Galindo-Castroa,I. and Fuenmayor,S.L.(2006). Polycyclic Aromatic Hydrocarbon Degradation by Biosurfactant-Producing Pseudomonas sp. IR1. Z. Naturforsch. 61c, 203-212.

[24] Lohmann R, Breivik K, Dachs J, Muir D. (2007). Global fate of POPs: current and future research directions. Environ Pollut 150:150-165.

[25] Margesin, R. and Schinner, F. (2001). Biodegradation and bioremediation of hydrocarbons in extreme environments. Applied Microbiology and Biotechnology 56(5-6): 650-663.

[26] Mohamed, I. A., Khalil, N. M. \& Mohamed, N. A. (2012). Biodegradation of some polycyclic aromatic hydrocarbons by Aspergillus terreus: African Journal of Microbiology Research, 6(16), 3783-3790.

[27] Morasch .B. , E. Annweiler, R.J. Warthman, R.U. Meckenstock. (2001). The use of a solid adsorber resin for enrichment of bacteria with toxic substrates and to identify metabolites, degradation of naphthalene, o-, and $\mathrm{m}$ - xylene by sulfate-reducing bacteria, J. Microbiol. Methods 44 (183-191).

[28] Mrozik, A., Piotrowska, Z., and Labuzek, S. (2003). Bacteria Degradation and Bioremediation of Polycyclic Aromatic Hydrocarbons. Polish Journal of Environmental Studies 12, 15-25.

[29] Norris RD (1994). Handbook of bioremediation. CRC, Boca Raton Oesterhelt D, Patzelt H, Kesler B (1998) Decomposition of halogenated hydrocarbons by halophilic bacteria. Patent DE19639894, April 9.

[30] Okoh, A. I. (2006). "Biodegradation alternative in the cleanup of petroleum hydrocarbon pollutants," Biotechnol. Mol. Biol. Rev 1: 38-50.

[31] Palanisamy,N., Ramya, J., Kumar, S.,Vasanthi,N., Chandran,P. and Khan,S.(2014). Diesel biodegradation capacities of indigenous bacterial species isolated from diesel contaminated soil .J.Environ Health Sci Eng.12:142.

[32] Rahbari M, Emtiazi G, Kamali S. (2011). Removal of toxic methyl tert-butyl ether by Naphthalene degradating bacterium isolated from freshwater. Jundishapur J Microbiol.; 4(3): 195-201.

[33] Samanta, S. K., O. V. Singh and R. K. Jain. (2002). Polycyclic aromatic hydrocarbons: environmental pollution and bioremediation. Trends Biotechnol. 20(6): 243-248.

[34] Sawadogo,A., Harmonie, O.C. Sawadogo, J.B., Kaboré,A.Traoré, A.S., and Dianou,D.(2014). Isolation and Characterization ofHydrocarbon-Degrading Bacteria from Wastewaters in Ouagadougou, Burkina
Faso. Journal of Environmental Protection, 5, 11831196.

[35] Schmitt, R.; Rohs, H.P. and Ckert, P.E. (1996). Biodegradation of aromatic hydrocarbons. Org. Geochem. 25(1): 41-50.

[36] Straube, W. L., Nestler, C. C., Hansen, L. D., Ringleberg, D., Pritchard, P.H. \& Jones-Meehan, J. (2003). Remediation of Polyaromatic Hydrocarbons (PAHs) through Landfarming with Biostimulation and Bioaugmentation: Acta. Biotechnol., 23, 179-196.

[37] Van Hamme, J.D.; Singh, A.; and Ward, O.P.( 2003). Recent Advances in Petroleum Microbiology, Microbiol. Mol. Rev., 67, 649.

[38] Walker, J.D. and Colwell, R.R. (1976c). Enumeration of petroleum degrading microorganisms. Appl. Environ. Microbiol. 31: 198-207.

[39] Ward, O. P., A. Singh and J. V. Hamme. (2003). Accelerated biodegradation of petroleum hydrocarbon waste. J. Ind. Microbiol. Biotechnol. 30: 260-270.

[40] Xia, X. H., Yu, H., Yang, Z. F., and Huang, G. H. (2006). Biodegradation of polycyclic aromatic hydrocarbons in the natural waters of the Yellow River: Effects of high sediment content on biodegradation. Chemosphere 65:457-466.

[41]Zhou,W., He,D., Li, X., Zhang,H.,Zeng,X. and Cheng,G.(2012).Isolation and characterization of naphthalene-degrading strains, Pseudomonas sp.CZ2 and CZ5.African Journal of Microbiology Research,7(1):1319.

Volume 6 Issue 12, December 2017

www.ijsr.net

Licensed Under Creative Commons Attribution CC BY 